\title{
Wolfgang Metzger and Thereabouts: Memories of a Formative Relationship
}

\section{Paolo Bonaiuto}

Sapienza Università di Roma - Department of Psychology (Italy)

doi: 10.7358/ecps-2016-014-bona

paolo.bonaiuto@uniroma1.it

\section{WOLFGANG METZGER E DINTORNI: MEMORIE DI UN RAPPORTO FORMATIVO}

\section{RiassunTO}

L'autore rievoca gli incontri avuti con Wolfgang Metzger, dell'Università di Münster, il quale veniva periodicamente a Bologna per ascoltare e discutere le ricerche dei giovani italiani. Gli incontri hanno occupato complessivamente poco più di un decennio (1961-1971). Gli episodi rievocati coinvolgono, oltre l'autore, anche i colleghi Renzo Canestrari, Giuseppe Galli, Carlo Umiltà, Giancarlo Trombini, Marino Bosinelli, Rudolf Arnheim, Cesare Musatti, Manfredo Massironi, l'artista Alberto Biasi e il pedagogista Giovanni Maria Bertin. Questultimo ha spesso mostrato apprezzamento per il fatto che, oltre agli aspetti della percezione, Metzger ha studiato altri processi cognitivi come la memoria, particolarmente importante per i processi di apprendimento. Vengono inoltre messi in luce alcuni aspetti del carattere di Metzger e le esperienze significative della relazione formativa tra il maestro e i vari allievi e studiosi. Si ricorda ancora la fiducia che questo maestro ha lasciato a proposito dell'importanza della fenomenologia sperimentale ed il ruolo avuto per la psicologia italiana.

A friend and old mentor of mine, Giuseppe Galli, now Full Professor at the University of Macerata, asked me to recapitulate on my memories of the meetings I had with Wolfgang Metzger, of the University of Munster, who periodically came to Bologna, at the university where I, too, was educated, in order to hear and discuss our research. He spoke fluent Italian. Here is a list of my memories I have managed to summarize. 


\section{A visit in Ravenna}

A particularly significant episode was the visit by Wolfgang Metzger and his wife (Juliane Metzger) to see the monuments of Ravenna, together Giuseppe Galli, Renzo Canestrari and myself (Figure 1).

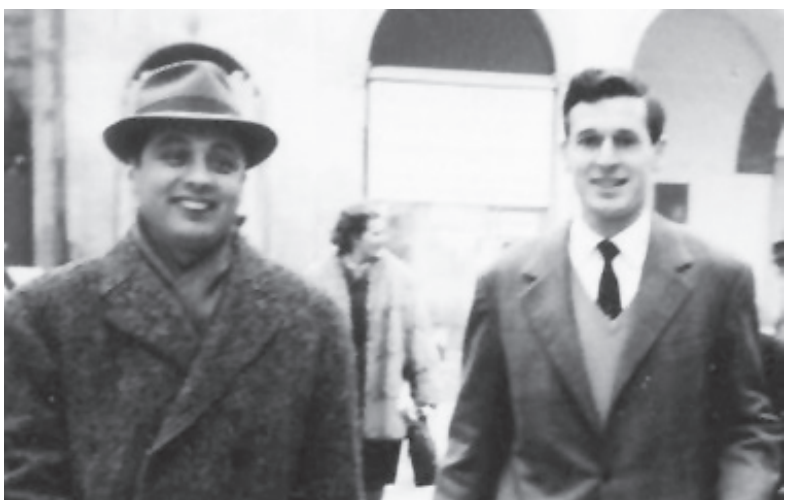

Figure 1. - The picture shows Renzo Canestrari (left) and the author (right) as they looked during their sightseeing in Ravenna (1961).

\section{An evaluation}

At one point, Prof. Metzger examined by «Board for Framing and Forecasting Field Effects» - a considerably large work (Bonaiuto, 1965a). After examining it, he said favorably: «It's a big job, but a good one». This episode followed on from an account of how, in doctoral theses in Germany, candidates often waffle by adding superfluous information. Metzger was critical of this habit and his appreciation of my work pleased me.

\section{«Das Liederkaroussell»}

On another visit, Frau Metzger told us of an interesting pastime of hers: collecting children's songs and nursery rhymes. She had, indeed, brought out a book in cooperation with Karl Heinz Taubert and Eva Joanne Rubin that contained a series of these songs and rhymes: it was entitled Das Liederkaroussell (The carousel of songs: Metzger, Taubert, \& Rubin, 1967). 


\section{The rotating "Hammer and Sickle»}

On another occasion, we wanted to create a variant of the «rotating trapeze» phenomenon. Metzger and I were with Canestrari and Carlo Umiltà, who looked on favorably. We tried various silhouettes, each one mounted on a rotating vertical axis. One of these was the famous "Hammer and Sickle» shape. Metzger commented ironically on the way the silhouette oscillated while rotating, as if to say that the symbol did not inspire security. Metzger's political views were, as we know, rather against those of the left ... Rudolf Arnheim once asked me which other German professors I had got to know. When I mentioned Metzger, he became visibly angry. When I later asked Cesare Musatti for a possible explanation of this behavior, he told me that Jewish people like Arnheim were angry because some German professors of psychology had been able to carry on with their work during the Nazi period. Metzger had, in any case, paid a harsh price for this: I was told that he had lost a son in the war. Some years later, a young man with wellgroomed light brown hair turned up in Bologna, in the lobby of the Institute of Psychology. He said he was Metzger's son - evidently the professor had another son. I have recently heard that the Metzgers had six children altogether.

\section{The overturned bucket}

The Institute of Psychology at the University of Bologna has a pavement running around its courtyard. One day, while Metzger and I were strolling along this pavement, we came upon an overturned bucket. Metzger stopped, bent down and, with a smile full of intentions, turned it the right way up as if to show that he was putting it back properly, along the vertical axis that in some way was neater as a position - that is, in a Gestaltistically proper direction.

\section{The expressive figure of "phenomenal causality without real movement»}

When I explained to Metzger my and Manfredo Massironi's criticism of Michotte's concept of phenomenal causality, showing him the figure of the wedge that produces and inflection of the vertical bars (Massironi \& Bonaiuto, 1966), he asked me for a copy of the figure so that he could include it in the new edition of his famous treatise Gesetze des Sehens (Metzger, 1953, $1975^{2}$ ) (under the auspices of Giancarlo Trombini). 


\section{«Scientific imagination»}

On several occasions, after hearing my exposition of one of my research projects, Metzger would complement me saying I had considerable scientific imagination. Imagination is synonymous with creativity, in modern terms: hence, "creativity in dealing with topics of Scientific Psychology". This is actually a quality that has often been attributed to me, even by Giuseppe Galli, for example, during a work we did together (Galli \& Bonaiuto, 1964); and this despite his, sometimes strong, critical attitudes and remarks: the socalled «Catilinaries», as I called them, recalling Cicero ...

\section{The gift of two art works and the doubts on their creator}

After 1964 I started being interested in the art movement called «Nuova Tendenza» («New Trend») or "Arte Programmata» («Programmed Art») and "Cinetica». I frequented the artists of this movement and became friends with some of them, such as Alberto Biasi of Padua. I decided to give Metzger two works by this artist because they contained interesting illusions - the socalled moire patterns. They consisted of two large and very flat square boxes closed by a transparent front façade with printed geometrical designs on it. The interference between these designs and others printed on the bottom of the box gave rise to the moire effects. One of these works was particularly original and elegant. I wonder where they have ended up after all these years: I suppose inherited by one of Metzger's living children. Metzger knew of my artistic inclinations and asked me if I had made these works (which bore no signature). I firmly denied they were mine - also so as not to take away the merit from their real creator: Alberto Biasi. But Metzger remained rather doubtful in any case ... (Bonaiuto, 1965b, 1966).

\section{The problem of authoritativeness. The beard}

During the student protests of 1968, Metzger also had some problems. Until that time he had always been clean-shaven and had slightly long hair (Figure 2). At this point, he decided to change his look by growing a beard. He said that, in this way, he would exude more authoritativeness in students' eyes. That is how he is depicted in encyclopedias (Figure 3), but I prefer to remember him as he looked before. 


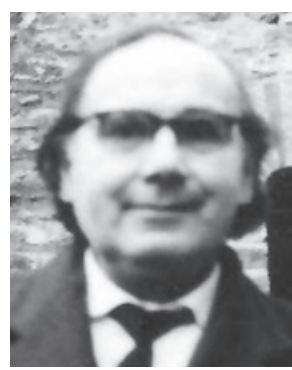

Figure 2.

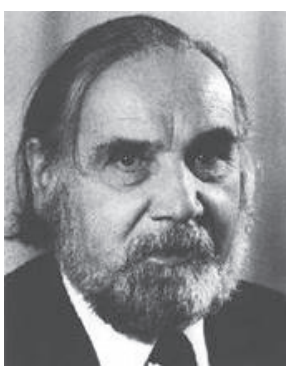

Figure 3.

\section{«Metzgerone»}

Within a small group of us, we would affectionately refer to him as the «Metzgerone» («Big Metzger»), as if to stress his importance through this accretive.

Aspects of his character: modesty and the need for cognitive complexity

In 1963 Metzger was asked to speak at the 2nd International Talk on Plastic Expression (Colloquio Internazionale sulla Espressione Plastica), in Bologna (Metzger, 1966). I was there, in the great hall of the Archiginnasio, the conference venue (Figure 4). When he arrived, Metzger went to sit among the audience instead of going up to the speakers' table. Marino Bosinelli quietly rebuked the organizers for not having accommodated Metzger in a more dignified fashion.

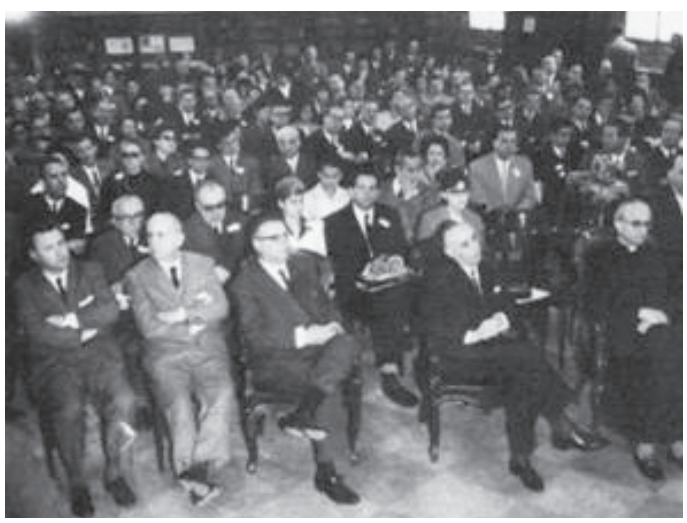

Figure $4 .-2^{\circ}$ Colloquio Internazionale sulla Espressione Plastica (Bologna, 1963). 
On the same occasion, the educationalist Giovanni Maria Bertin showed appreciation for the fact that, besides the aspects of perception, Metzger had also listed other cognitive processes, such as memory, which is particularly important in musical experience, and the feeling of genuineness of the work. For us very young scholars at the time, those meetings were a kind of Ph.D. (which did not exist then) and were largely enjoyable, unlike the seminars held at the same time at the universities of Trieste and Padua, which gave us a feeling of inferiority - almost making us «feel like cretins».

On the whole, these meetings took place in a period of just over a decade (1961-1971). It is fitting to praise the memory of the man here because the events recalled are still clear despite the fact that they occurred about fifty years ago. Metzger left me with great confidence in my abilities and in the importance of experimental phenomenology. His role for Italian psychology and for that of Bologna of the time was significant.

In some respects, this work has written itself: I evoked and refined the sentences at night, in between my sleeping moments, and then set them down on paper in the light of day.

\section{REFERENCES}

Bonaiuto, P. (1965a). Tavola d'inquadramento e di previsione degli «effetti di campo» e dinamica delle qualità fenomeniche [Table to frame and foresee the "field effects" and dynamics of phenomenal qualities]. Giornale di Psichiatria e Neuropatologia, 42 (4), Suppl., 1443-1685.

Bonaiuto, P. (1965b). Analisi di opere di «Nuova Tendenza» [Analysis of works of "New Tendency»]. Arte Sintesi, 3(9-10), 1-14 e 24-28.

Bonaiuto, P. (1966). Lineamenti d'indagine fenomenologica sperimentale in rapporto con problemi ed esperienze della progettazione visuale [Outlines of experimental phenomenological investigation in relation with problems under experiences of visual design]. Il Verri, 22, 24-65.

Galli, G., \& Bonaiuto, P. (1964). Proporzionalità fenomenica e proporzionalità geometrica nell'ingrandimento grafico di figure rettangolari [Phenomenal proportionality and geometric priportionality in the graphic magnification of rectangular figures]. Rivista di Psicologia, 58(4), 351-355.

Massironi, M., \& Bonaiuto, P. (1966). Ricerche sull'espressività. Qualità funzionali, intenzionali e relazione di causalità in assenza di «movimento reale» [Investigations on expressiveness: Functional and intentional qualities and causality relation in absence of «real movement»]. Rassegna di Psicologia Generale e Clinica, VIII, 1-42. 
Metzger, J., Taubert, H., \& Rubin, J. (1967). Das Liederkaroussell [The carousel of song]. München: Annette Betz Verlag.

Metzger, W. $\left(1953,1975^{2}\right)$. Gesetze des Sehens [Laws of vision]. Frankfurt a M.: Kramer.

Metzger, W. (1966). I fondamenti dell'eperienza estetica [The foundations of aesthetic experience]. Relazione al $2^{\circ}$ Colloquio Internazionale sulla Espressione Plastica, Bologna, 1963. In G. Maccagnani (a cura di), Atti del $2^{\circ}$ Colloquio Internazionale sull'Espressione Plastica (pp. 767-780). Imola: Galeati.

How to cite this Paper: Bonaiuto, P. (2016). Wolfgang Metzger and thereabouts: Memories of a formative relationship [Wolfgang Metzger e dintorni: memorie di un rapporto formativo]. Journal of Educational, Cultural and Psychological Studies, 14, 191-197. doi: 10.7358/ecps-2016-014-bona 